Article

\title{
On the Links between Caricatures and Animated Films in Communist Eastern Europe
}




\begin{abstract}
This article analyses and maps the links between caricature and animated film, as well as their development during the post-World War II era, in communist Eastern Europe. The article also deals with the specific nature of animation production under the conditions of political censorship and the utilisation of Aesopian language as an Eastern European phenomenon for outmanoeuvring censorship.
\end{abstract}

Animated film has long been closely connected with caricatures; the pioneers of Western animation, such as Émile Cohl, James Stuart Blackton, Winsor McCay, John Randolph Bray, Paul Terry, Max Fleischer and many others, were known as caricaturists before they turned to animation. In addition, several animated characters were born and won initial popularity on the humour pages of newspapers, and travelled on to the world of cinema with their authors. In Animated Cartoons: How They Are Made, Their Origin and Development (1926) Edwin Georg Lutz observes that many trailblazers of animation launched their career as 'comic graphic artists' (Lutz 1926: 8-10). A number of other authors have also emphasised the importance of caricatures in the development of animated film (e.g. Pikkov 2010:31, Solomon 1987: 13, Wells 1998: 188). Yet, besides acknowledging the significance of these impulses, no exhaustive studies have been written on the links between caricatures and animated film and this field remains largely unresearched. To some extent, Donald Crafton has examined these issues in Before Mickey: The Animated Film, 1908-1928 (1984) and Emile Cohl, Caricature, and Film (1990), but the scope of these books is limited to the pre-World War II period.

This article aims to map the connections between caricatures and animated film, as well as their development during the post-World War II era, with the primary focus being on Eastern Europe, which is defined here as a geographical area and more importantly as a political space dominated by the Soviet Union after World War II. The area was generally called the communist sphere or Eastern Bloc. However, in order to understand the specific circumstances related to the intertwined fields of caricature and animation in Eastern Europe during the second half of the 20th century, an overview of prior key developments in both the Western and Eastern hemispheres needs to be provided first.

\section{THE NATURE OF CARICATURE} In the context of this article, I understand caricature to be a simplified graphic image that amplifies, for the purposes of comic or grotesque effect, certain distinctive features of what is being represented. The essence of caricature lies in parody, i.e. drawing attention to human weaknesses or shortcomings of social and political life. The concept originates from the Italian word caricare, meaning 'to charge,' 'to load', 'to exaggerate'.

The history of caricature runs in parallel to art history; simplified and grotesque graphic images can be traced back to the medieval period. Still, in the modern sense of the word, caricature took root in Germany of the Reformation Age, spreading, along with satirical literature, to the neighbouring 
countries in the first half of the 16th century. The proliferation of the caricature form, especially in terms of political and personal caricatures, was facilitated by the development of graphic art and the invention of the printing press in the late Middle Ages, while earlier the satirical songs of minstrels had performed the same function (Wright 1875: 347). When considering the 'caricaturesque' in a broader sense, I mean the depiction of something in a highly exaggerated or simplified manner, a grotesque abstraction.

\section{CARICATURES START TO MOVE AND TURN INTO FILMS}

The similarity between early animation and caricatures stems partly from technical aspects, i.e. from the fact that drawing (reproducing) a character had to be easy and the figure itself sufficiently clear and highly contrasted, in order to stand out even if the film or printed page was of low quality. Other similarities include accentuating satiric aspects and simplification in the creation of memorable characters. Indeed, the earliest drawn films (and specifically those, since animated film also employs many other techniques) are characterised by a strong emphasis on the caricaturesque. For instance, Walt Disney taught his animators that "the first duty of the cartoon is not to picture or duplicate real action or things as they actually happen - but to give a caricature of life and action' (Barrier 1999: 142).

The first films of Disney Studios were strikingly caricaturesque and consisted mostly of sequences of moving caricatures. Disney's early concept prescribed the creation of moving caricatures. In due course, as the field of animation developed and its technical arsenal expanded, the production of Disney Studios, as well as other major studios, became more epical and the initial cartoonish quality gradually disappeared. In addition to the introduction of more advanced techniques, the films also changed in terms of their content. Romantic screen adaptations of fairy tales became the norm for feature-length animated films (Snow White and the Seven Dwarfs, directed by David Hand, William Cottrell, Wilfred
Jackson, Larry Morey, Perce Pearce, Ben Sharpsteen, USA, 1937; Pinocchio, directed by Ben Sharpsteen, Hamilton Luske, Bill Roberts, Norman Ferguson, Jack Kinney, Wilfred Jackson, T. Hee, USA, 1940; Bambi, directed by David Hand, James Algar, Samuel Armstrong, Graham Heid, Bill Roberts, Paul Satterfield, Norman Wright, USA, 1942). In a similar manner, early live-action filmmaking was heavily influenced by the circus and vaudeville and only later became an art form for telling stories.

From early on, the production of animated films in the United States developed as a collective, studio-based undertaking, rather than the enterprise of individuals. In America, the popularity of the first animated films and the rapidly growing network of cinemas facilitated a constant demand for new animated films, which in turn created favourable conditions for setting up the animation industry.

In contrast to the United States, where major animation film studios flourished before World War II, European animation relied on individual authors with diverse personal styles. Among them were filmmakers inspired mainly by caricatures (Émile Cohl, Robert Lortac, Cavé), directors striving to tell epic stories (Lotte Reiniger, Ladislas Starevich, Berthold Bartosch), as well as artists experimenting with animated images (Walter Ruttmann, Hans Richter, Viking Eggeling, Oskar Fischinger).

World War II halted the development of European cinema in its tracks, many filmmakers emigrated and the continuity of film production was disrupted. In addition to filmmakers, a large number of European artists also went to the United States, bringing with them the 'spirit of modernism'. The strong American film industry was enriched by the creative investigations and experimentations of various modernist art schools, exemplified by Disney's collaboration with Salvador Dalí or the American works of Oskar Fischinger. With the influx of European talent, "US took the lead role in avant-garde film, as it did with painting when New York replaced Paris as the cultural capital of modernism' (Rees 1999: 57). 
During World War II, the United States became the world's leading film producing country and the pioneer of technical inventions in the field of audiovisual culture. In the narratives of the world history of animation, Western Europe is typically seen as 'a fertile area for experimental and avantgarde animation' that, in particular, led the way in the early days of cinema, soon losing its predominant position to the United States, while Eastern European statefunded animation industry is recognised for providing financial security and criticised for curtailing creative freedom (Cavalier 2011:13).

\section{DEVELOPMENTS IN ANIMATED FILM IN THE EASTERN BLOC}

Compared to the rest of the world, the development of animated film in Eastern Europe took a different route.

\begin{abstract}
Between 1945 and 1989 ... the development of these countries was levelled to a significant extent and dictated by Soviet policies in the spheres of economics and culture. [---] Whatever happened in the Soviet Union directly influenced the cultural climate in the countries of the Eastern Bloc, and often events in the USSR were replicated in the Eastern Bloc (such as the 'Thaw' that followed the demystification of the cult of Stalin's personality in the late 1950 s or the stagnation of the Brezhnev period). (lordanova 2003: 20-21)
\end{abstract}

After the October Revolution of 1917, Soviet Russian animated film was highly receptive to creative experiments. For instance, Dziga Vertov's (1896-1954) avant-garde enterprises, Kino-Glaz (Кино глаз or Cine-Eye) and Kino-Pravda (Кино-Правда or Cine-Truth), employed several animators. The first Soviet animated film, Soviet Toys (Cовеmскue игрушки, Russia, 1924), was made under Vertov's direction. This caricaturesque drawn animation depicted class struggle, portraying the confrontation between workers and peasants and a wealthy capitalist. Cinema, including animated film, was mainly seen in Soviet Russia as a propagandistic tool. The best known Soviet animated film directors of the period are Vladimir Suteyev, sisters Valentina and Zinaida Broomberg, Ivan Ivanov-Vano, Olga Khodataeva and Nikolai Khodataev.

For a while, Soviet Russian animation artists were relatively free to experiment, just as the entire post-revolutionary society was open to various forms of innovation. New forms of expression and approaches were explored in cinema, literature and theatre, as well as in visual art. Yet these artistic liberties did not last for long: "Initially avant-garde and satirical, Soviet animation changed in the middle of the 1930s with the establishment of socialist realism ... Control was tightened, and Stalin-era animation concentrated mostly on didactic animation for children' (Klots n.d.: 5).

Soviet animation and caricatures have often been regarded as a means of embellishing the state of affairs and concealing its true nature. This tendency of airbrushing, typical of Soviet visual culture in general, can be traced back to the satirical 'Rosta (Российское телеграфное агентство or Russian Telegraph Agency) windows' - propaganda posters accompanied by texts in verse. At the same time, Soviet animation is also characterised by the combination of folkloristic elements with new, proletarian imagery. Frequently, traditional folklore characters were represented in the current Soviet setting, as in Valentina and Zinaida Broomberg's Ivashko and Baba-Yaga (Ивашко и Баба-Яга, Russia, 1938). This tendency proved to be an enduring one, lasting for decades to come as testified, for example, by Gennady Sokolsky's 1981 Ivashko from Pioneers' Palace (Ивашка из Двориа пионеров, Russia).

With rare exceptions, Soviet animated films in the immediate post-war years were didactic in nature and propagandistic in their message. Soviet animation was directly influenced by the officially established tenets of socialist realism, and the 
employment of caricaturesque imagery was one of the few methods for circumnavigating those principles to a certain extent. The animated films produced in Eastern Europe during the first decade and a half of the post-war period emulated the Soviet production of the 1930s - 'mainly created for children, oriented towards moral and civic teaching, and resistant to stylistic changes' (Bendazzi 1994: 151).

Khrushchev's Thaw, which commenced after Stalin's death in 1953, relaxed the political pressure to some extent, and this also changed Eastern European animation, which became more varied in terms of subject matter and scope of technical devices. Although the communist society in general remained insular, Khrushchev's Thaw diversified the means of expression available to communist cultural life, including animation. As Anatoliy Klots has observed, the 'naturalistic cartoons that often employed rotoscoping' were gradually replaced with new methods, frequently inspired by the avant-garde aesthetics of the 1920s, "causing a more cartoonish, abstract, and even surrealist appearance' (Klots n.d.: 5).

The Story of a Crime (История одного nреступления, Russia, 1962) by Fyodor Khitruk can be considered the first (and for quite a few years the only) post-World War II Soviet animated film that violated the strict codes of socialist realism. Khitruk, who later became one of the most famous Soviet animation artists, launched his career during Khrushchev's Thaw. Seeing animation as 'a synthesis of caricature and poetry' (Wells 2012: 506), he intentionally, and consistently, employed a caricaturesque approach to evade the limits of socialist realism. For him, as well as for many other Soviet and Eastern European animation artists, the caricature-like, comedic form of expression functioned like a 'permissive filter' that foregrounds the 'joke', presenting works of these kind as 'something that should not be taken overly seriously' and concealing their status as acts of 'orthodox authored artmaking' (Wells 2012: 504-505).

Andrei Khrzhanovsky's Glass Harmonica (Стеклянная гармоника, Russia, 1968) is another characteristic example of how the diminished political constraints and aesthetic diversification influenced Soviet animation. Featuring hybrids of humans and animals, as well as metaphorically loaded, elongated perspectives, Glass Harmonica's distinctly surrealist content and form was heavily influenced by the surrealist perspective of one of its authors, Ülo Sooster, an Estonian surrealist artist who was working in Moscow. At the time of its release the pictorial language of the film came across as highly innovative and modern - something that would have been quite impossible to achieve either before the liberating breeze of Khrushchev's Thaw or during the days of stagnation that followed the Prague Spring of 1968. Even though its production began during the period of increased creative freedom, Glass Harmonica was still an extremely problematic film - it was wellknown due to word of mouth, but had only limited distribution as Leonid Brezhnev's cultural policies 'tightened the screws' on the art community. In addition, its production process was complicated by delays and demands for re-editing.

Giannalberto Bendazzi notes that the Iron Curtain dividing Western and Eastern Europe was much more visible in animated film than in live-action cinema or any other art form (Bendazzi 1994: 151). The Western European animation industry concentrated primarily on the production of feature-length films for children (that were frequently rather mediocre copies of Disney) and, as in the United States, animated shorts remained the privilege or obsession of only a few authors. In Western Europe, the spread of television in the 1950s created a certain demand for animated commercials, but even this did not lead to the establishment of a tradition or industrial infrastructure comparable to that of live-action cinema. By contrast, the Eastern European animation industry was subsidised by the state, which resulted in a solid production infrastructure and 17 April 2015. 
created a stable environment for production. Short forms dominated the field, but feature-length animations were also made. Animated films were just as widely distributed as live-action cinema on both large and small screens. Studios employed a large number of people who were interested in a smooth production process and keeping subversion within acceptable limits. On the one hand, state funding ensured the stability of animated film production and established proper industrial conditions, but on the other, it created the need to compromise with the authorities. The position of script editor was established at the studios to fulfil this task. The editors' responsibilities included both artistic guidance and control over political correctness; "thorough editorial corrections ... also partially functioned as ideological cleansing methods' (Klimova 2013: 59-60).

The censorship of the artistic domain has a long history in the Eastern Bloc, and it can be traced back to the pre-revolutionary Russian Empire. Although the 1917 revolution obliterated the imperial apparatus of censorship, in 1922 Soviet authorities set up a new body for censorship and protection of state secrets. Called Glavlit (Главное управление по охране государственных тайн в печати) it operated, together with its sub-institutions, until the collapse of the Soviet Union.

Jaan Ruus, a legendary Estonian film critic who also had a long career as a script editor, has described this role in Soviet Estonia as follows,

In bureaucratic jargon, the editor's mission was to be the politruk (политрук, 'political instructor') and to ensure that the artist would work 'for the cause' and move in the right direction without aberrations. Yet, in Soviet Estonia's cinematic system, the editor paradoxically took the opposing role, by becoming literally the director's advocate. (Trossek 2008: 40)
Limits were constantly challenged in the communist art system, and in this struggle, the script editor played a crucial part as the mediator between the author and the authorities. Thus, the degree of film directors' creative freedom depended to a great extent on the script editors who were responsible for overseeing their projects. And the filmmakers, operating under the constraints of censorship and the script editors, developed a distinctive language of expression,
where allegory became a certain form of 'straightforwardness' and its decoding by the public became the dominant means of comprehension. Thus, a situa- tion emerged where an animated film, for example, was not just a film, but also something else - a cultural sign that was quite dan- gerous and meaningful for the existing power discourse. (Trossek 2006: 102)

\footnotetext{
AESOPIAN LANGUAGE

Artworks created in Soviet Union and Eastern Europe were often filled with subtexts, and the audience actively engaged in both creating these subtexts and looking for what had been written 'between the lines'.

Instead of communicating their ideas directly, the Soviet and Eastern European authors were often forced to employ allegory and ambiguous references, or Aesopian language. Aesop (Aisōpos, c. 620-564 BCE) was a slave and storyteller in ancient Greece whose fables often relied on allegory. His simple tales, usually featuring animals as characters, were highly critical of the authorities. Based thereon, 'critical commentar[ies] on the political regime in veiled form' are termed 'Aesopian language' (Goldstein 2000: 24, cited in Klimova 2013: 25). Double-coded artworks created under communist conditions are good examples of Aesopian language.

The difference between allegory and Aesopian language lies in 'the presence of a censoring organ, which affects the authors'
} 
writing practices and the readers' interpreting choices' (Klimova 2013: 13). Lev Loseff adds that Aesopian language requires three agents: an author, a reader and a censor. Decoding Aesopian language is not only the job of a reader; it also involves an author and a censor. According to Loseff, the expression 'Aesopian language' was developed by the writer Mikhail Saltykov-Shchedrin in the 1860s, and has since been used by critics and the intelligentsia. Originally a characteristic of Russian literature, the term has gradually spread to other media, such as visual art, music and film (Loseff 1984:3-5).

It is important to underscore that not all authors intentionally created political subtexts, but as art was widely censored by the state, one can assume that all authors who were aware of this censorship also carefully considered any possible political references in their works, and used Aesopian language at least unconsciously. Along these lines David Vseviov et al. argue that

by the early 1930, in addition to pervasive official censorship, Soviet artists had unconsciously adopted an even more effective control mechanism - selfcensorship. This means that the creative work of artists-caricaturists, just like that of other publicly acknowledged authors, followed a principle that has been termed 'the three U principle' - yzadamb ('to guess'), yzodumb ('to please'), уиелеть ('to survive'). (Vseviov et al. 2013: 51)

\section{COMMUNIST CARICATURE AND ANIMATION AS VISUALISED AESOPIAN DIALECTICS}

Many humour magazines were published in post-war Eastern Europe - Szpilki in Poland, Eulenspiegel in East Germany, Dikobraz in Czechoslovakia, Ludas Matyi in Hungary, Jež and Kerempuh in Yugoslavia, Krokodil in Russia, Pikker in Estonia, etc. Compared to Western Europe, the number of humour magazines was greater in
Eastern Europe due to state funding, and they provided much-needed extra income for a considerable number of animation filmmakers. The ideas of the authors also moved between these two fields. Sometimes the links between caricatures and animated films were quite direct, and an idea tested in caricature form would be elaborated in animation. For instance, Avo Paistik, a prominent Estonian animation artist, has recalled how a caricature of a man being manipulated by machinery that he saw in a cultural weekly provided the inspiration for the protagonist in his film Sunday (Pühapäev, Estonia, 1977; see Kiik 2006: 106).

In comparison to the rest of the world, post-war Eastern European animation undoubtedly had more intimate connections with caricature, and this was due, at least partially, to the popularity of humour magazines and their state funding.

In 1956, the caricaturists of the Yugoslavian humour magazine Kerempuh formed an animation studio at the Zagreb Film studio (established in 1953). The caricaturesque style of animations produced at Zagreb Film started to serve as a muchadmired and often-emulated model for all of Eastern Europe. Technically rather simple, these caricaturesque, intellectual animated films became the main production article of Zagreb Film and the critics started to refer to their authors collectively as the Zagreb School. Today, this term is used to define all Eastern European caricaturesque animated films with strong "political overtones and social-critical implications' (Orosz 2017). In 1962, Dušan Vukotić's Erzatz (Surogat, Yugoslavia, 1961), produced at Zagreb Film, became the first non-US animated film to win an Oscar.

The examples of Eastern European caricaturesque animated films produced outside Zagreb Film, but which are still considered to ideologically belong to Zagreb School, include...And Plays Tricks (...ja teeb trikke, Estonia, 1978) by Priit Pärn and Bartakiada (Czechoslovakia, 1985) by Oldřich Haberle. 
Tango (Poland, 1980) by Zbigniew Rybczyński, one of the most eminent products of Eastern European auteur animation, can also be regarded as a caricaturesque work in the spirit of Zagreb Film. Although more complex in style than most examples of caricaturesque animation, Rybczyński's film is strongly rooted in the tradition of so-called 'communal' humour, i.e. satire targeted at contemporary living arrangements, primarily in an urban setting. Parodies of this kind were common in both printed media and animated films, due partly to the fact that they provided ample opportunities for drawing attention to the shortcomings of socialist society and criticising socialist life without the immediate fear of censorship. Tango features a cramped apartment in a typical 'Soviet Bloc block', a prefab residential building. In the film, 36 characters representing the full spectrum of social stereotypes of the time move around in a single small room without ever acknowledging each other's existence (Figure 1). In its absurdly realist mode, Tango provides a claustrophobic, yet hilariously caricaturesque, representation of everyday socialist life and its environment.

The caricaturesque style of the Zagreb School was also a major source of inspiration for Rein Raamat, an eminent Estonian animation artist. Although Raamat did not draw caricatures himself, his The Water Bearer (Veekandja, Estonia, 1972), the first Estonian post-war drawn animation, relies heavily on 'Zagrebian' caricaturesque absurdity and humour. Furthermore, the film's visual style, created by Rein Raidme, is obviously influenced by Dušan Vukotić's imagery. The Water Bearer was produced at the Joonisfilm Studio at Tallinnfilm, which was established by Raamat in 1971. The film became a yardstick for a number of subsequent Estonian animations, as well as for the directors-artists who joined the studio. Many of them had previous experience as caricaturists and continued this line of work while also making films.

In Soviet Estonia, the main platform for publishing caricatures was Pikker magazine, as well as the humour pages of several newspapers and magazines (Sirp ja Vasar, Edasi, Noorte Hääl, Noorus). Caricaturists also participated in various specialised competitions. Yet an ideologically incorrect concept could create serious problems for both its author and the periodical that published the caricature. For instance, in 1979, Heiki Ernits, a young animation director who had studied in Moscow at the Higher Courses for Scriptwriters and Directors, was expelled and received a 'publication ban' because his caricature in Pikker was deemed inappropriate. The caricature resembled a famous photo of Lenin's family (Figures 2A and 2B). Another telling example is Priit Pärn's caricature Sitta kah! (literally Just Shit!, but roughly Whatever! or I Don't Give a Shit!), published in the cultural weekly newspaper Sirp ja Vasar in 1987. The picture depicted a man in a padded jacket (that could be read as a symbol of Soviet mentality) standing on a broken horse-drawn wagon and throwing a piece of manure in the shape of the map of Estonia (Figure 3 ) out of the wagon. It caused a political scandal and the case was discussed by the Central Committee of the Communist Party of Estonia and resulted in the dismissal of the newspaper's editor-inchief.

\section{THE PECULIARITIES OF EASTERN EUROPEAN HUMOUR}

Compared to the contemporary democratic world, caricatures and humour in communist Eastern Europe generally had a rather different content and meaning. Soviet jokes were special
because of the extremely repres- sive and intrusive nature of the political and social system and in particular the absence of free- dom of speech. The jokes were far more important to the people who told them than are the jokes told in democratic societies, where jokes are merely a laughing mat- ter, sheer entertainment. (Davies 2011: 217) 
This so-called 'official humour' also existed in the Soviet system and it was often referred to as satire, but here I am speaking about unofficial or 'folkloric' humour, i.e. 'many hundreds, quite possibly thousands, of political jokes told by the citizens of the former Soviet Union and satrapies of its empire' that made fun of the social and political system, as well as of its authorities, and which, according to several commentators, "constitute one of the largest bodies of jokes ever invented' (Davies 2011: 213-214; see also Krikmann 2002: 840).

Typically, communist caricatures infrequently used words or speech bubbles. This is because a word tends to have a more specific meaning than an image and the use of the wrong word could not be as easily excused as 'artistic play' with forms and shapes. In the case of a visual image without any verbal addition, the author could rely on the 'safety net' of ambiguity and thus minimise the risk of political liability. Eastern European caricaturists often used absurdity, self-irony and certain surrealist subject matter, which made it difficult to assign a clear message to a picture. Many caricaturists, as well as other artists, intentionally created works that could be interpreted in various ways. It was the editors, not authors, who usually added a general caption or an explanatory text to the caricatures. At the same time, the communist print media employed numerous politically trustworthy caricaturists who produced 'correct' caricatures, which were either commissioned, or at least approved, by the political elite. For example, Boris Yefimov, one of the most prolific Soviet caricaturists, recalled in his memoir that there were occasions in his career, when commissions came directly from Stalin who not only prescribed a particular subject matter but also interfered personally in the creative process by correcting the captions and sometimes even the drawing (Vseviov et al. 2013: 51).

Typically, the editorial board of a particular publication determined the subject matter for the caricatures, and it also provided general guidelines, sometimes going to extremes in terms of reversing the intended message. For instance, until the collapse of the Soviet Union, capitalists (i.e. the bourgeoisie) were generally depicted wearing a top hat or bowler and smoking a cigar. Aside from the obviously distorted political joke, this image also carried the message that Soviet caricaturists lived in such isolated conditions that they didn't even know that no one in the 'free world' wore early 20th-century clothes any more. Official Soviet caricature gradually turned into a parody of its own visual clichés.

Another peculiarity of Eastern European humour is the immense popularity of political anecdotes, which spread by the word-of-mouth. This genre was practically non-existent in the capitalist world, or at least far less popular (Davies 2011: 300). The vast popularity of political anecdotes eloquently illustrates a situation where jokes targeted at the authorities provided a certain counterweight to the lack of freedom of speech. Thus, conversations in the Eastern Bloc often started with the question, 'Have you heard the latest joke?' And this usually meant a political or in some way socially critical anecdote.

In the Soviet sphere of influence, a unified field of folkloristic humour, or rather a system of underground humour, was established that expressed a certain repressed collective identity. It formed in opposition to the totalitarian propaganda and highlighted the shortcomings and absurdities of the surrounding social reality. Taboo topics and threat of repressions only fuelled the popularity of underground humour.

Christie Davies suggests that the great popularity of jokes targeted at the authorities had a direct connection to the collapse of the Soviet Union or, at the very least, these anecdotes undermined people's loyalty to the communist system (Davies 2010: 10). The massive spread of anecdotes has also been regarded as a form of resistance (Obrdlik 1942: 712, Pi-Sunyer 1977: 182) or as a kind of consolation (Cochran 1989: 272, Hong 2010: 61).

Eastern European literature has left an extensive legacy of humour classics, but Jaroslav Hašek's The Good Soldier Švejk 

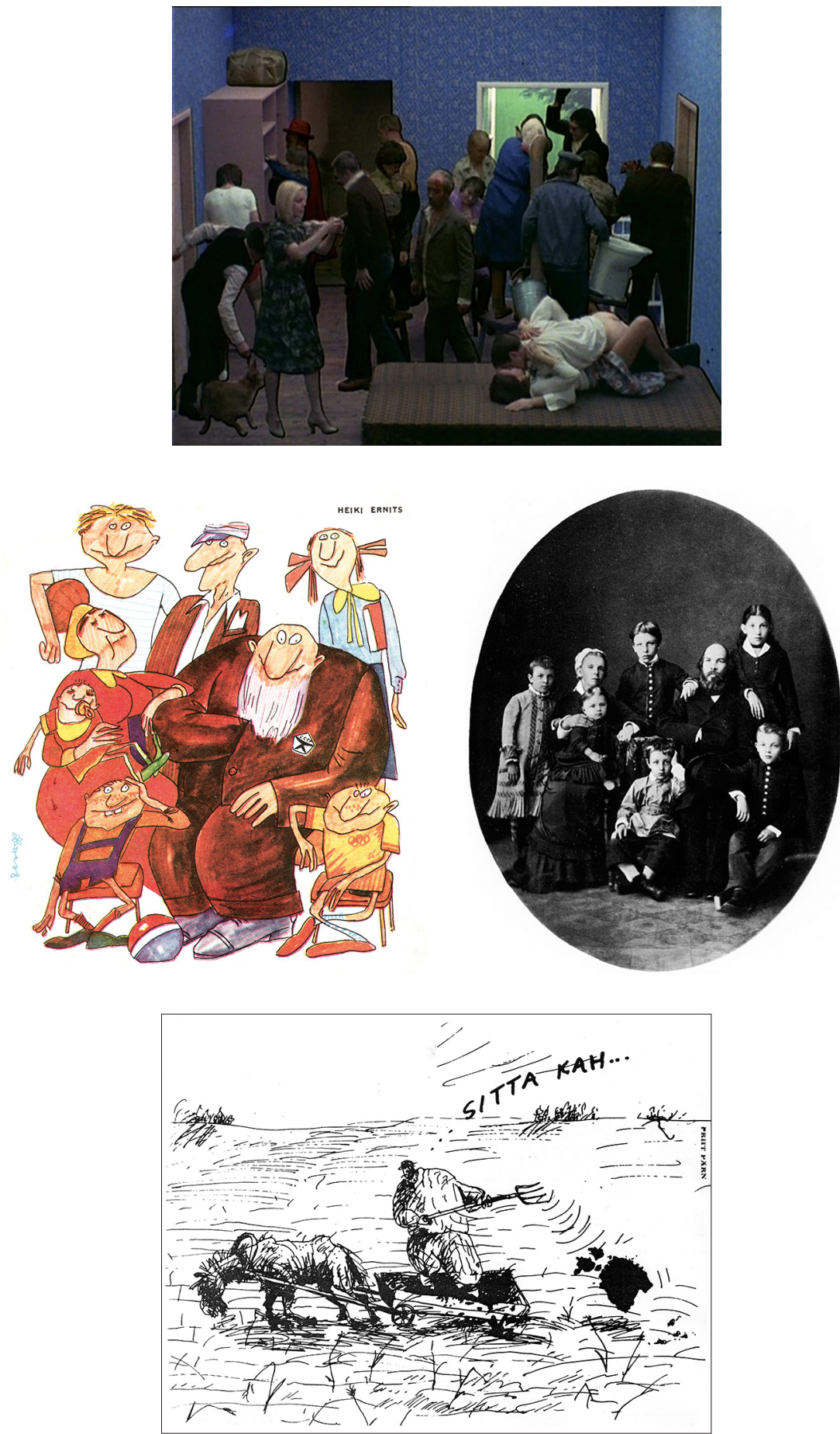

FIGURE 1. Zbigniew Rybczyński, Tango (Poland, 1980).

FIGURE 2A. A caricature by Heiki Ernits, published in Pikker in 1979, based on a famous photo of Lenin's family.

FIGURE 2B. The Ulyanov family. Author unknown.

FIGURE 3. Priit Pärn, Sitta kah! (I Don’t Give a Shit!, 1987). 
(Osudy dobrého vojaka Švejka za svétové valky, 1923) deserves a special attention. A number of scholars (e.g. Ajanović n.d., Tőke 2008) consider this novel, and particularly its protagonist Švejk, the epitome of Eastern European humour. Just like several other folklore heroes (such as the Czech Hloupy Honza [Dull Honza], Hungarian Ludas Matyi [Mattie the Goose-boy] or Estonian Kaval Ants [Crafty Hans]) of the region, Švejk's cunning dexterity permits him to succeed in any situation. The 'ingenuously idiotic' behaviour of Švejk, who stands for the lower class in general, provides the key to understand the protagonists of Eastern European caricatures and animated films. The typical Eastern European 'hero' is a rather passive character with an ironic outlook, and instead of initiating events, he just gets mixed up in them against his will - '[u]nder occupation, during wars or revolutions, his only shelter and shield is a special kind of humor, full of pessimism, absurd and surrealism' (Ajanović n.d.).

In the words of Paul Wells, 'Eastern European humour like this may be viewed as black irony - the surreality is a philosophic and political statement as well as the vehicle for humour' (Wells 1998: 161). Furthermore, Midhat Ajanović argues that surrealist irony and ironic black humour are inscribed into the history of Eastern Europe. This preference for dark humour can be traced back to the days of the Habsburg Monarchy and Austro-Hungarian Empire, which included many different small nations. The latter were practically cut off from the highest ranks of the authorities, which led to anecdotes and ironic black humour targeted at them. In fact, Luigi Lombardi-Satriani even suggests that folklore as a whole is a 'culture of contestation', which defined itself in opposition to the official culture of upper classes (LombardiSatriani 1974, cited in Krikmann 2002: 840).

Similarly, in post-war Eastern Europe that was to a great extent under the dominance of the Soviet Union, the relationship of the common people with the central authorities was distant and one-sided.
The anarchy of the authorities was compensated by jokes on them. In the communist period, humour also became a certain social code - an anecdote was enough to determine the interlocutor's political attitudes and codes of behaviour. Humour turned into a certain cryptic text, or, as Priit Pärn observes in the film Pärnography (Mees animatsioonist, Estonia, 2005), 'Laughter comforts the downcast.'

Surrounded by a society charged with political jokes, artists reflected folkloric humour in their works, either intentionally or unintentionally. In contrast to political anecdotes that had no chance of ever being published in print, animation filmmakers succeeded in expressing critical stances towards the dominant system and its agents by means of artistic abstraction and Aesopian language.

In Soviet Estonia, one of the most widespread anecdotal formulas featured an Estonian, a German and a Russian as its protagonists. These tales of 'three nations' typically highlighted the resourcefulness of the subaltern Estonian, in contrast to the stupidity or misfortune of the representatives of the other two nations - the principal historic 'masters' of Estonian territory. Paistik's Three Jolly Fellows (Naksitrallid I-II, Estonia, 1984-1987) provides an eloquent example of how this originally anecdotal formula was reflected in animated film. In Three Jolly Fellows, the titular fellows collectively represent the Estonians who successfully triumph over the cats and rats that take turns in attacking an idyllic provincial town (Figures 4-6). When making the films, Paistik and Eno Raud, the author of the book that served as the literary source for the films, envisioned the rats as symbolising Russians and the cats as standing for Germans (Tõnson 2013). Arguably, the domestic audiences easily understood these allusions to foreign aggressors.

The creative interaction between anecdotes and animated films also worked the other way around, with animation characters sometimes crossing over into popular humour. It was precisely the immense popularity of their life in animation that 

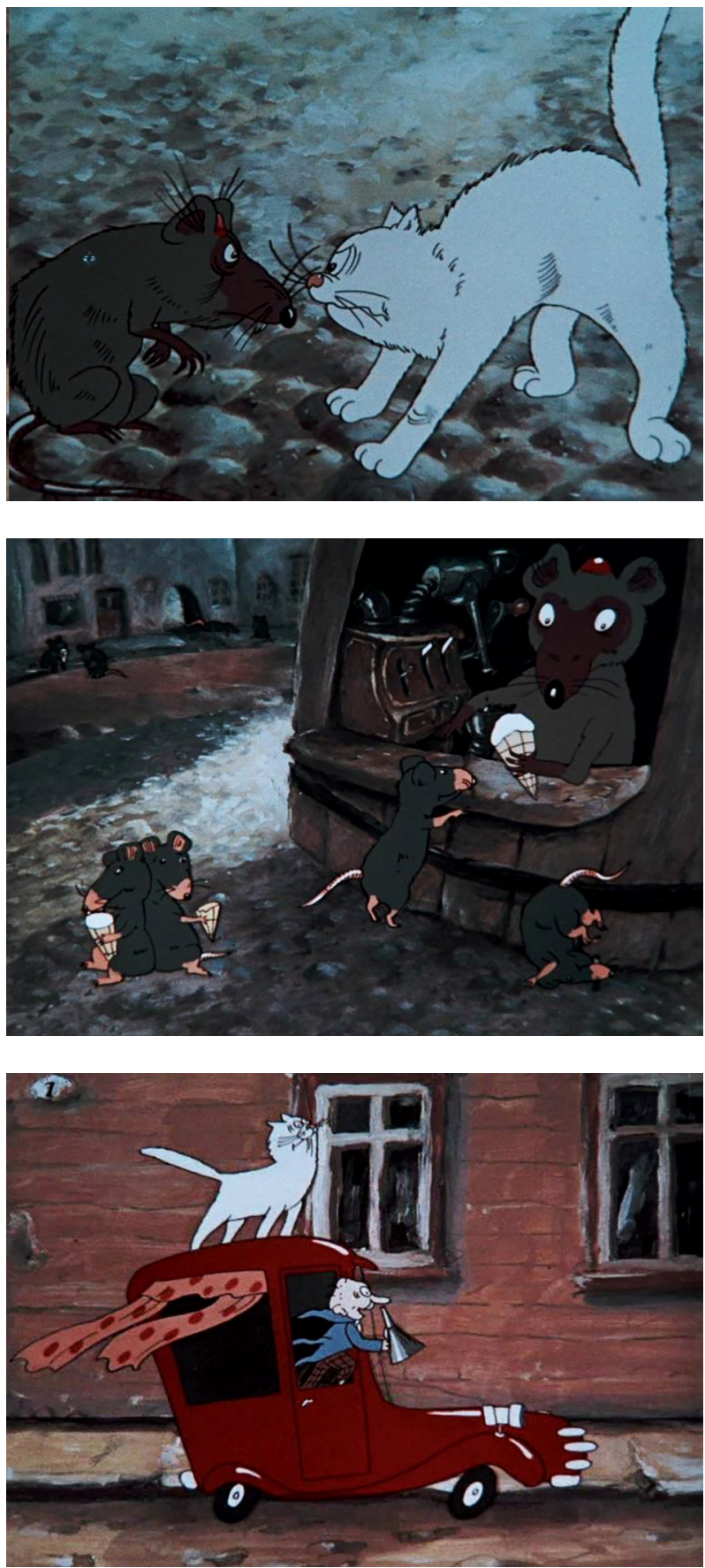

FIGURE 4-6. Avo Paistik, Three Jolly Fellows (Naksitrallid II, Estonia, 1987). 
gave enormous and lasting currency to such anecdotal figures as the Hedgehog in Fog (from Yuri Norshtein's legendary animation Hedgehog in Fog [Ёжик в тумане, Russia, 1975]), and Gena the Crocodile and Cheburashka (from Roman Kachanov's beloved stop-motion short Gena the Crocodile [Крокодил Гена, Russia, 1969]).

\section{SUMMARY AND THE CONTEMPORARY SITUATION}

To a large extent, animated film is rooted in caricatures and comic strips because many pioneers of animation were working as caricaturists. Animated film in the United States gradually abandoned this initial connection in favour of epic feature-length animations. Meanwhile, in European animation the short format, which is also characteristic of caricaturesque humour, took root. Compared to feature films, shorts are cheaper and easier to produce, hence providing more opportunities for taking artistic as well as economic risks. Concentrating on short films, European animation developed into a diverse art form. Following Disney's achievements, American mainstream animation continues to tell epic stories and flaunt its technical novelties, aiming to feat its competitors with technical excellence. Since film production depends heavily on a distribution system that favours the feature-length form, mainstream cinema focuses on making feature-length films.

The post-war division of Europe into the communist East and the capitalist West also had an impact on animated film of those regions. In Eastern Europe, animated film was funded by the state, but also strictly censored, both in terms of content and form. In a search for creative alternatives, Eastern European animations often relied on double-coded Aesopian language. Doubtlessly, the great number of humour magazines, as well as the many animation filmmakers that contributed to them, also facilitated the prominence of caricaturesque animations. In addition, the enormous popularity of anecdotes and other 'street jokes' caused the abundance of caricaturesque animated films in totalitarian society.
Although the political system has changed, Eastern European animation continues to feature remarkably strong caricaturesque elements, even if the popularity of caricatures has waned and most of the humour magazines that published them have fallen to the margins of the new mediascape.

Aesopian language has also retained some of its importance in Eastern European animation. Time and again, Švejk-like characters reappear, and their misfortunes, as well as the conflict between their human expectations and the random ways of the world, still provide inspiration for numerous directors. In Cinema of the Other Europe, Dina Iordanova emphasises that, despite the regime changes, Eastern and Central European animation continues the tradition of lyricism, surrealism, magical realism and avant-garde (Iordanova 2003: 150).

At the same time, Eastern and Western European animated films have become more similar because European cultural sphere is increasingly integrated - film production and funding observe the same principles throughout the European Union, the films circulate in the same channels of distribution and are screened at the same festivals. Furthermore, since 1989, with the fall of the Berlin Wall and the end of the Cold War, "[t] here was a massive emigration of animation professionals [from Eastern European countries], many of whom are now employed by companies across Western Europe, Canada and the US' (Iordanova 2003: 32).

Over the last decades, a number of European and American art schools have introduced curricula for animation, which have turned out a considerable number of auteurist animation filmmakers. In addition to traditional channels and sources, modern digital solutions have opened up new opportunities for film distribution, as well as for funding. In turn, digital channels have created greater demand for animated films, especially shorts, which include many caricaturesque animations. 


\section{REFERENCES}

Ajanović, Midhat n.d. 'Animation and Realism. Midhat Ajanović. http://www.ajan.se/index. php?option =com_content\&task=view\&id=30\&lte mid=36 (1 October 2017).

Barrier, Michael 1999. Hollywood Cartoons: American Animation in Its Golden Age. Oxford: Oxford University Press.

Bendazzi, Giannalberto 1994. Cartoons: One Hundred Years of Cinema Animation. London: John Libbey. Cavalier, Stephen 2011. The World History of Animation. Berkeley: University of California Press.

Cochran, Robert 1989. “"What Courage!”: Romanian "Our Leader" Jokes'. - The Journal of American Folklore 102, 405, 259-274.

Crafton, Donald 1984. Before Mickey: The Animated Film, 1898-1928. Cambridge, MA; London: MIT Press. Crafton, Donald 1990. Emile Cohl, Caricature, and Film. Princeton: Princeton University Press.

Davies, Christie 2010.'Jokes as the Truth about Soviet Socialism. - Folklore: Electronic Journal of Folklore 46. http://www.folklore.ee/folklore/vol46/davies.pdf (1 October 2017).

Davies, Christie 2011. Jokes and Targets. Bloomington, Indianapolis: Indiana University Press.

Goldstein, Robert Justin 2000. 'Introduction'. - Robert Justin Goldstein (ed.), The War for the Public Mind: Political Censorship in Nineteenth-Century Europe. Westport, London: Praeger, 1-34.

Hong, Nathaniel 2010. 'Mow 'em All Down Grandma: The "Weapon" of Humor in Two Danish World War II Occupation Scrapbooks'. - Humor: International Journal of Humor Research 23, 1, 27-64.

Iordanova, Dina 2003. Cinema of the Other Europe:

The Industry and Artistry of East Central European Film. London, New York: Wallflower Press.

Kiik, Silvia 2006. 'Avo Paistiku võitlused võimu, tsensuuri ja Goskinoga Il'. - Teater. Muusika. Kino 5, 97-107.

Klimova, Olga 2013. Soviet Youth Films under Brezhnev: Watching Between the Lines. PhD thesis. University of Pittsburgh. http://d-scholarship.pitt.edu/19634/1/ Klimova_ETD_2013.pdf (1 October 2017).

Klots, Anatoliy n.d. 'Depicting the Trickster: Soviet Animation and Russian Folktales'. https://jsis. washington.edu/wordpress/wp-content/uploads/ sites/13/2016/05/Klots.pdf (1 October 2017).

Krikmann, Arvo 2002. 'Sissejuhatavat huumorist ja rahvanaljast: ained, mõisted, teooriad'. - Keel ja Kirjandus 12,833-847.

Lombardi-Satriani, Luigi 1974. 'Folklore as Culture of Contestation'. - Journal of the Folklore Institute 11, 1/2, 99-121.

Loseff, Lev 1984. On the Beneficence of Censorship: Aesopian Language in Modern Russian Literature. München: Verlag Otto Sagner in Kommission.

Lutz, Edwin Georg 1926. Animated Cartoons: How They

Are Made, Their Origin and Development. New York:

Charles Scribner's Sons. https://archive.org/details/

cu31924075701304 (1 October 2017).

Obrdlik, Antonin J. 1942. "'Gallows Humor" -

A Sociological Phenomenon'. - American Journal of Sociology 47, 5, 709-716.

Orosz, Anna Ida 2017. 'Protest in Motion: Discover How Political Animations Thrived Behind the Iron Curtain' The Calvert Journal, 19 April. http://www.calvertjournal. com/articles/show/8114/animation-communism-neweast-soviet-censorship (1 October 2017).

Pikkov, Ülo 2010. Animasophy: Theoretical Writings on the Animated Film. Tallinn: Estonian Academy of Arts. Pi-Sunyer, Oriol 1977. 'Political Humor in a Dictatorial State: The Case of Spain'. - Ethnohistory 24, 2, 179-190. Rees, A. L. 1999. A History of Experimental Film and Video: From the Canonical Avant-Garde to Contemporary British Practices. London: British Film Institute.
Solomon, Charles 1987. The Art of the Animated Image: An Anthology. Los Angeles: The American Film Institute. Tőke, Lilla 2008. 'Idiots on the Ball: Švejkism as a Survival Strategy in the East European Imaginary'. Eva Näripea, Andreas Trossek (eds.), Via Transversa: Lost Cinema of the Former Eastern Bloc. Tallinn: Estonian Academy of Arts, 157-175.

Tõnson, Margit 2013. 'Kolm põlvepikkust maailmaparandajat'. - Eesti Ekspress, 27 September. http://ekspress.delfi.ee/kuum/kolm-polvepikkustmaailmaparandajat?id=66791253 (15 October 2017). Trossek, Andreas 2006. 'Rein Raamatu ja Priit Pärna joonisfilmid nõukogude võimudiskursuses. Ambivalents kui allasurutu dominantne kultuurikood totalitarismis' / 'Animated Films of Rein Raamat and Priit Pärn in the Discourse of Soviet Power: Ambivalence as the Dominant Cultural Code of the Oppressed in Totalitarianism?. - Kunstiteaduslikke Uurimusi 15, 4, 102-128.

Trossek, Andreas 2008. 'When Did It Get Political? Soviet Film Bureaucracy and Estonian Hand-Drawn Animation'. - Eva Näripea, Andreas Trossek (eds.), Via Transversa: Lost Cinema of the Former Eastern Bloc. Tallinn: Estonian Academy of Arts, 31-45.

Vseviov, David; Belobrovtseva, Irina; Danilevskij, Aleksander 2013. Vaenlase kuju. Eesti kuvand Nõukogude karikatuuris 1920.-1940. aastatel. Tallinn: Valgus.

Wells, Paul 1998. Understanding Animation. London: Routledge.

Wells, Paul 2012. 'Laughter Is Ten Times More Powerful Than a Scream: The Case of Animated Comedy'. - Andrew Horton, Joanna E. Rapf (eds.), A Companion to Film Comedy. Malden, Oxford: John Wiley \& Sons, 497-520.

Wright, Thomas 1875. A History of Caricature and Grotesque. London: Chatto and Windus. https:// ia601408.us.archive.org/34/items/historyofcaricat00wrig/historyofcaricat00 wrig.pdf (1 October 2017). 